'frontal' zone onriched in silica and the 'rear' zone enriched in olivine. Applying this process to the primitive Earth one would postulate a dogasification of the original material and formation of the atmosphere, hydrosphere and lithosphere through geochemical migration of elements.

Methods of study are discussed by V. N. Florovskaya and L. I. Ovchinnikova $(11,69 ; 1963)$, who describe the study of coals, bitumens and fossil plants by means of the 'luminescent microscope', using ultra-violet light. Ya. L. Blikh and V. M. Bondarenko $(9,85 ; 1964)$ describe a 'deep-seated' geological survey method, measuring the intensity of cosmic rays in boreholes and mines.

Among accounts of new discoveries is the article by V. P. Solononko $(9,102 ; 1964)$, who describes a newly discovered volcanic region in Eastern Siberia, in which 15 volcanoes of Quaternary age have been mapped and numerous traces of earthquakes recorded. This region is centred on the Udokan ridge situated between the rivers Vitim and Olekma, both tributaries of the River Lena. Siberian mosses of the Permian era, first discovered by M. F. Neiburg in 1941 , are described by S. V. Meien $(5,73 ; 1963)$.

\title{
TWENTY-FIVE YEARS OF CRUDE OIL PRODUCTION IN GREAT BRITAIN
}

$I^{\mathrm{N}}$ 1939 production of crude petroleum from English oilfields amounted to 3,145 tons; in 1963 the total was 122,764 tons, After a quarter of a century it is interesting to take stock of the enterprise and expertise which have made possible this progress, humble though it may seem when moasured by overseas standards. This has recently boen done by R. (X. W. Brunstrom of the Exploration Department, British Petroleum Co., Ltd., London, in an article entitled. "BP's First Quarter Century of Crude Oil Production in Britain" (BP Magazine, No. 13, 1964; London). Actually, the first oilfield discovered in Britain was at Hardstoft, Derbyshire, in 1919, drilled for the then Ministry of Munitions, which ceased further explorations for oil in 1922. For various roasons private companies did not pursue the quest until some years later; it was, in fact, the Potrolcum (Production) Act, 1934, which created the fillip to industrial onterprise in oil finding. This act vested in the Crown the ownership of all mineral oil not discovered to that date; it supplied just the attractive operating conditions under which oil companies felt justified in spending energy, time and particularly large sums of moncy in the search for oil in Britain. British Petroleum pioneered this new phase by drilling wells in the southern counties between 1936 and 1938, for example at Portsdown, near Portsmouth, and in Dorset, but with no success. But in the latter year natural gas was struck at Cousland, Midlothian; carly in 1939 it was found at Eskdale, Yorkshire. A freak find was that of a shallow field at Formby, near Southport, Lancashire, in May 1939, which has produced more than 9,800 tons of crude oil since then, but with no geological encouragement of commercial extension. Soon after Formby came the wellknown discovery of oil at Eakring, Nottinghamshire, a significant turning point in this history. "Eakring, apart from being a significant oilfield in its own right, was immediately seen to be the first of a group of similar fields awaiting discovery. Formby brought hope of further success, but Eakring brought certainty." Eakring owed much to geological acumen at the time; coal mine and borehole cvidence, confirmed by seismic refraction surveys, helped to establish it and, by continuation particularly of the geophysical technique, other discoveries in that region were made-Kelham Hills, 1941, Dukes Wood, 1941, Caunton, 1943. A small field discovered at Nocton, south of Lincoln, in 1943 yielded 40 tons of oil, then went to water. Although numerous exploration wells were drilled during the ensuing 10 years, they were not successful until a field was discovered at Plungar, Leicestershire, in 1953. A technique known as 'secondary recovery', that is, injection of water through wells drilled around the periphery of an oilfield, driving oil towards the production wells by a water flood, had boen successfully employed to arrest decline in production in the Eakring group, and by 1953 had become standard practice in most British fields. The discovery of Egmanton oilfield in 1955 started another bout of exploration activity which has continued to the present time. "An average of one new oilfield has been found in the East Midlands in each of the last seven years, and three new gas ficlds have been found but are not yet in production, The new fields are of varying sizes, and the largest, (Kainsborough, is probably as big as Egmanton." One particularly gratifying success is recorded from Kimmoridge, Dorset, where a 943-ft. well was drilled in 1937 and abandoned as a dry hole; a well drilled to $1,791 \mathrm{ft}$. near tho same site in 1959 found oil and thus the Kimmoridge oilfield came into being. It is noteworthy that: "Up to the present there have been only three non-BP oil wells in Britain - one at Hardstoft and two at the small Esso field named Midlothian, near Dalkeith, Scotland".

\section{ARID ZONE FORESTRY}

T HE subject of afforostation and reforostation in arid zones is dealt with comprehensively in a publication entitled Tree Planting Practices for Arid Zones*, which has recently been revised by Dr. A. Y. Goor for the Food and Agriculture Organization of the United Nations.

About one-third of the world's land surface lios in the arid and semi-arid zones where the annual rainfall is less than 24 in. The arid zone, with loss than 12 in. of rainfall a year, includes some of the great deserts of the world, but it is in parts of the semi-arid zone that afforestation and reforestation schemes have been and are being tried. These schemes and others aimed at improving the natural tree growth can make useful contribution to the general

* Food and Agrioulture Organization of the United Nations. FAO Forestry Development Paper No. 16: Tree Planting Practices for Arid Zones. Pp. xii $+233+2$ maps. (Thome: Food and Agriculture Organization of the
United Nations; London: H.M.S.0., 1963.) 158; 3 dollars. welfare of tho pooples by bringing to localized areas a lessening of wind erosion, a reduction of evaporation from the soil and of plunt transpiration, and in fixing moving sand, arresting gully and sheet erosion, in providing rsthetic benefits and in supplying timber and other products. But where the forester is called on to try to bring about these improvements through trees, he is usually faced with a set of climatic and edaphic factors which does not make his task an easy one. Very often he has to deal with soils that have been degraded by over-grazing, fire or ovor-cutting. He is often very restricted in the choice of species for planting and has to rely on a limited number of drought-resistant ones. The forester working in those conditions will find this handbook very useful, for it includes methods of seed collection and its handling, nursery and planting techniques. Perhaps some 